This is an Accepted Manuscript of an article published by Representation, available online: https://doi.org/10.1080/00344893.2019.1669692

\title{
Who represents the poor? The corrective potential of populism in Spain*
}

\author{
Matthias Scantamburlo \\ (Aston University)
}

\begin{abstract}
Scholarly research assumes populism enhances democratic inclusion by giving voice to groups that are not represented by political elites and by obliging them to be more attentive to their preferences. Empirical studies have focused on this dynamic more indirectly looking at the emergence of new conflict dimensions, leaving the representation of marginalised groups underexplored. This article contributes to filling this gap by analysing party competition over poverty responsiveness at the regional level in Spain during the Great Recession. Combining Regional Manifestos Project data with issue sub-categorisation, the article shows that populist parties, which emerged during the economic crisis, represent the poor to a greater degree in their political agenda than establishment parties. At the same time, the latter have reacted to new competitors by being more attentive to the poor in their political discourse. As a result, supply-side adaption to include proposals tackling poverty and social exclusion increased the representation of the poor in regional spaces of political competition.
\end{abstract}

Keywords: populism; poverty; responsiveness; representation; Spain

\footnotetext{
* I would like to thank the special issue editors Annika Werner and Heiko Giebler as well as the anonymous reviewers for their thoughtful comments. Special thanks also go to Sonia Alonso and Braulio Gómez.
} 


\section{Introduction}

This article analyses the effect that the rise of populist parties in the aftermath of the European Great Recession has had on the substantive representation of poor citizens. Scholarly research assumes populism enhances democratic inclusion by giving voice to groups that are not represented by political elites and by obliging them to react and change their political agenda to include these marginalised preferences (Mudde \& Kaltwasser, 2013; Kaltwasser, 2012; Roberts, 2016). While studies on the effects of populism on political representation have focused on this dynamic more indirectly looking at the emergence of new conflict dimensions or the congruence between parties and voters on the main dimensions (Huber \& Ruth, 2017), the representation of politically marginalised groups has been left underexplored. According to Bornschier (2017) one of the main difficulties is finding a yardstick to assess whether the representation before the presence of populist challenger parties was good or bad, and for which segments within the electorate.

Despite these evident difficulties, however, a look at the literature on political representation shows that liberal democracy always works in favour of better-off citizens. Scholarly research (Bartels, 2008; Elsässer, Hense, \& Schäfer, 2017; Rigby \& Wright, 2013) repeatedly demonstrates that poor citizens have limited voice in the democratic arena and that the electoral and decision-making spheres are systematically less responsive to their preferences. Besides mainstream party convergence around market liberalism, the main reason for this is unequal political participation (Schäfer, 2018; Solt, 2008). Poor citizens are less likely to vote and their preferences therefore less likely to enter the political process. Political parties in first instance have few incentives to represent their demands. Leaving the most disadvantaged out of the system breaks with the principle of representation that should characterise the elections of representative democracy. While this dynamic is inherent to most Western 
democracies, it may well explain why the economic crisis hit the poor hardest by worsening their poverty.

Populist parties, which massively grew in the aftermath of the Great Recession and especially in many severely crisis-affected economies of Southern Europe, campaign against the elites and claim to represent the true voice of 'the people' (Laclau, 2005). As the deck of democracy is always stacked in favour of the better-off and the political process largely unresponsive to everyone else, in their anti-elite campaign populist parties indeed point to a real democratic deficit (Schäfer, 2018). However, do populist parties contribute to correct this deficit by being more responsive to the poor in their political agendas than other parties? Have establishment parties become more attentive towards the most disadvantaged in response to the growth of populist challengers? These are the questions that this article aims to answer.

To do so, this study focuses on political parties' issue attention towards poor citizens during the Great Recession in Spain, a country that has been strongly affected by the crisis and figures among those countries in Europe showing the highest levels of poverty. The main political consequence of the crisis in Spain has been the rise of new parties - Podemos and Ciudadanos - who to a greater or lesser extent match with current definitions of populism and whose discourse structures around the democratic regeneration of the political establishment (Scantamburlo, Alonso, \& Gómez, 2018). While most studies on the political effects of the crisis focus on the national level, I scale my analysis down to the level of individual Autonomous Communities (ACs). Since new challengers first emerged at the regional level and the administration of public services deemed most important for tackling poverty, such as health and social services, is a regional field of competence, Spanish ACs represent a good case to explore these parties' impact on the representation of the poor. Given its unique character, the Spanish case is helpful for a first exploration of the expected dynamics, opening up new avenues for further testing. 
In line with the above-mentioned studies, the main argument is that populist parties appeal to voter groups that have been excluded from the representation process (Mudde \& Kaltwasser, 2013; Roberts, 2016). More concretely, as establishment parties tend to ignore low-income citizens particularly in contexts of hardship (Anderson \& Beramendi, 2012) populist parties present themselves as a more authentic representative of their preferences. Using data from party manifestos by combining the content analysis of the Regional Manifestos Project (Alonso, Gómez, \& Cabeza, 2013) with issue sub-categorisation (Horn, Kevins, Jensen, \& Van Kersbergen, 2017) the article shows that the rise of populist challenger parties in Spain led to increased poverty responsiveness in regional political spaces of competition through supplyside adaption concerning proposals tackling poverty and social exclusion.

The article is structured as follows. I first introduce the theoretical background regarding populism, its relationship with representative democracy and the representation of socioeconomically marginalised groups. After the introduction to the case, the fourth section presents the theoretical expectations that will guide the comparative analysis. Section five introduces the main data and operationalisation. The empirical findings are presented in section six. The seventh section concludes with a discussion of the results.

\section{Populism, Representation and Political Exclusion}

The term populism is highly contested and different labels have been used to define it. Most scholars agree on Mudde's (2004, p. 543) ideational approach that defines populism as 'thin' ideology considering society 'to be ultimately separated into two homogenous and antagonistic groups - 'the pure people' versus the 'corrupt elite', and which argues that politics should be an expression of the volonté générale (general will) of the people'. Although populist parties vary from the left to the right, the core conception of populism as 'thin' ideology implies a rather specific perspective on democracy (Kriesi, 2014). At the heart of this perspective lies the ideal of democratic representation, which is associated with a maximum claim of 
responsiveness (Caramani, 2017). Populist parties identify the general interest in the will of the people and the representatives have to reflect it by acting 'on behalf' of this interest. Accordingly, their discourse revolves around a permanent crisis of representation, which is the result of unresponsive elites who escaped popular control (Ruth \& Hawkins, 2017).

This unmediated concept of political representation stands in a tense relationship with liberal definitions of democracy. Building on Dahl's (1971) classic two-dimensional conceptualisation of polyarchy, Mudde and Kaltwasser (2013) refer to this relationship as double-edged, whereby populism can be a threat but also a corrective for (liberal) democracy. While the threat component refers to undermining democratic contestation by weakening the rule of law, checks and balances or the protection of minorities, the corrective potential assumes populism to enhance the democratic inclusion of politically and socioeconomically marginalised citizens. The latter point paved the way to reflections about populism as a mode of political representation and the rise of populist parties as an answer to failed or ineffectual political representation, thereby questioning the degree to which liberal institutions are able to achieve the goal of connecting popular inputs with political outputs (Mair, 2013; Roberts, 2016; Ruth \& Hawkins, 2017). Conceptualising it as a top-down and anti-establishment way of mobilising constituencies lacking capacity for autonomous political expression, Roberts (2016) rather defines populism as

a natural (though not inevitable) mode of appealing to and incorporating mass political constituencies where representative institutions are weak or widely discredited, and where various forms of socioeconomic or political exclusion leave many citizens marginalized or alienated from such institutions (p. 519).

From an empirical point of view, therefore, questions whether populist parties fill a representative gap concerning excluded citizens, but also the consequences of their electoral success on the representation of these citizens' interests, become relevant. Coined by Pitkin (1967), the concept of substantive representation refers to a responsive political decision- 
making process, which should be informed about and reflect a wide range of interests and preferences within the electorate. Adopting such a perspective, existing research has investigated if the government participation of populist parties translates into the substantive representation of the poor (Ruth \& Hawkins, 2017). Rethinking the functioning of representation, however, scholars have called for more nuanced analyses by taking into account a broadened picture and referring to 'anticipatory representation' (Celis, Childs, Kantola, \& Krook, 2008) as a core feature of substantive representation. Instead of merely transferring interests, the representatives actively frame the (under-)represented and their preferences through 'claim-making' (Saward, 2006) and influence substantive representation in a more dynamic process through agenda setting already before elections (Chaney, 2015).

Such a focus allows getting to the empirical connection between political representation and party strategic behaviour concerning political exclusion. The literature on party competition shows that parties strategically draw attention to certain issues in order appeal to and mobilise determined voter groups (Budge \& Farlie, 1983). As they aim to mobilise the excluded, populist strategies represent a quite specific type of political appeal. According to Resnick (2012) they can include an eclectic mix of leftist and neoliberal elements, but are distinguished by their focus on social inclusion 'offering policy packages oriented around providing goods, services, and recognition to those who have been excluded from the economic and political status quo' (p. 8). While economic conditions as such may not be conducive to populism, severe inequalities and exclusion from traditional institutions of representation provide raw ingredients for the effectiveness of such strategies. Indeed it have not only been left-wing populist parties but also right-wing or 'neoliberal' ones, which in times of economic crises, weak organized labour and parties attracted support of the poorest sectors through targeted antipoverty measures (Roberts, 1995). 
Targeted programs have a smaller fiscal impact than universal ones, but their political logic is functionally equivalent, as material rewards are exchanged for political support (Roberts, 1995). What differs are the recipients. While targeted policies such as poverty relief schemes directly address low-income groups, universal welfare (e.g. public health or education) concerns all citizens. ${ }^{1}$ Being group specific, targeted policies are especially well suited for manipulation by vote-seeking parties (Jusko, 2008). By setting them high on their political program, parties not only claim their own representative capacity among the addressed group, but also influence the broader 'party system agenda' (Green-Pedersen \& Mortensen, 2010) forcing competitors to address issues they would rather avoid. While opposition parties may promise benefits in order to blame incumbents for poor economic conditions, legislators may use them when the support of the poor is essential to maintain office. The decision to campaign through such appeals however depends on the broader economic and political context.

\section{Poverty Responsiveness: Structural and Political Factors}

The (uneven) responsiveness of political parties to different income groups has been explained through its relation with (unequal) political participation. Enough evidence illustrates that political abstention is concentrated in the poorest sectors of society and that it is induced by policies oriented towards the 'middle classes' (Elsässer et al., 2017; Solt, 2008). Poorer citizens view inequality as favouring the preferences of the better-off and thus are less likely to participate because they conclude that politics is 'simply not a game worth playing' (Solt, 2008, p. 58). Consequently, it has been argued that the demands of poor citizens do not enter the decision-making process, as parties in first instance have no incentives to represent those demands. Yet, as the decision to vote and the representation of interests are interrelated, the

\footnotetext{
${ }^{1}$ While there is a lot of scientific debate about who actually profits, it has been argued that universal welfare regimes benefit the 'middle class' more than any other group (Fernandez-Albertos and Manzano 2012). Leaving these debates aside, what matters for this article is the political logic behind groupspecific policies.
} 
electoral participation of poor citizens hinges also upon parties' mobilisation efforts. Beginning such efforts, in turn, depends on the expected gains in terms of votes (Anderson \& Beramendi, 2012).

Given that they constitute their most 'natural' voter base, scholarly research on crossnational differences in the mobilisation of poor voters has focused the analysis on left-wing parties stressing the interplay of structural and political factors influencing political mobilisation (Anderson \& Beramendi, 2012; Pontusson \& Rueda, 2010). Concerning structural factors, it has been argued that higher levels of income inequality reduce the incentives for dominant left-wing parties to target poor voters as it increases the probability that poor citizens will ignore those efforts making it harder to clear the cost-benefit threshold for parties (Anderson \& Beramendi, 2012; Rigby \& Wright 2013). The main political factor shaping party behaviour towards the poor is party competition. Anderson and Beramendi (2012) show that the presence of a challenger on the left creates incentives for dominant left-wing parties to mobilise poor voters. When competing for low-income voter support within their own political spectrum parties adjust their platforms to challengers and even counteract the negative influence of income inequality on the mobilisation of the poor.

The most straightforward reason for such a behaviour is an expected electoral threat and an endangered potential to gain office (Meguid, 2008). By strategically accommodating their political agendas to those of competitors, dominant parties try to signal to the public that they are (now) seriously committed about an issue they had ignored in the past. This is supposed to work due to dominant parties' higher chances of government participation and policy implementation. According to Meguid (2008), mainstream parties' responses to the rise of challengers have important effects on their electoral success. While anticipatory increases in low-income voter mobilisation indeed limit the output for challengers, following Anderson and Beramendi (2012), they do so even more in the presence of high levels of inequality. Greater 
inequality increases the mobilisation costs for all parties contributing to reinforce the preemptive effects of an accommodative strategy. Thus, in combination with increased party competition on the left, electoral turnout among the poor is likely to increase in more unequal countries.

Emphasising the interplay between structural and political factors in determining party strategic behaviour towards the poor, the following analysis tries to acknowledge it in the context of the Great Recession. While reinforcing the above-mentioned dynamics due to poorer economic conditions, such a context has changed the configuration of actors. In contrast to normal times, where the mobilisation of the low-income vote is likely to take place between parties on the left, I expect competition for the appeal towards the poor to unfold between establishment and new populist parties across the entire political spectrum. A major economic crisis like the Great Recession constitutes a 'critical juncture' threatening the political establishment as a whole and accelerating pre-existing processes of party system change (Hernandez \& Kriesi, 2016). Indeed, in all severely crisis-affected economies that have been, or are still, subject to interventions by the Troika, the electoral decline of mainstream parties has not favoured traditional challengers but new anti-establishment parties from left and right (Marcos-Marne, Plaza-Colodro, \& Freyburg, 2019).

\section{Introduction to the Case}

Before presenting the hypotheses based on these lines of reasoning, I first provide some background information about the case study of this paper. Spain during the economic crisis seems to offer a setting particularly well suited for an exploration of the impact that the rise of populist parties had on the representation of the poor as it corresponds to the context described above by Roberts (2016), i.e. highly discredited institutions, partisan convergence and a great amount of economic and political exclusion. The reasons for a regional perspective are at least threefold. First, Spanish ACs differ in relation to the number of poor citizens, which allows the 
impact of structural factors to be explored. Second, public services in Spain have been devolved to ACs. Third, new populist challenger parties form the left and right first entered the political arena at the regional level.

With more than 12 million people living in poverty and risk of exclusion, over a quarter of the population, Spain is the Western European country with the highest poverty rate (EAPN 2018). Since the unfolding of the Great Recession, the number of people living in poverty or at risk of exclusion has increased by around one million. While the economically and politically excluded in fact may not be so new it is certainly true that the crisis has punished the most disadvantaged more intensely by worsening their poverty (Gómez \& Trujillo 2011). Unlike the national level, the values at the regional level indicate high cross-regional variation, showing a clear North-South divide. Whereas in the Southern ACs the mean poverty rate is about $28 \%$ in the Northern ACs, it is below 15\%. Analysing the relation between political and economic exclusion in Spain, Gómez and Trujillo (2011) confirm that the constituencies with the highest abstention rates (of up to 75\%) are also the ones showing the highest levels of poverty. Indeed, the lack of resources among the most disadvantaged groups of Spanish society is the most important factor in generating political exclusion.

Another reason for adopting a regional focus is the devolution of public services to ACs. Decentralisation makes regional governments responsible for providing citizens with services that are directly related to their daily needs. Consequently, in decentralised states issues concerning welfare are of high relevance at the subnational level (Vampa, 2016). ${ }^{2}$ Yet, concerning the political conflict over welfare Spain has been characterised as an outlier case, given that the two dominant parties, the conservative Popular Party (PP) and the Social Democratic Workers Party (PSOE), have been very similar over the issue. While this may be

\footnotetext{
${ }^{2}$ A comparison of party manifesto data from the MARPOR and the RMP (see below) in the period under analysis (2007-2017) shows that the salience of welfare issues in regional party manifestos (19.23; SD $6.51)$ is significantly $(\mathrm{p}<0.01)$ higher than in national party manifestos $(15.54$; SD 4.96).
} 
partly linked to regionalisation, Fernandez-Albertos and Manzano (2012) argue that in Spain welfare issues to some degree crosscut the ideological conflict. Distinguishing between universal and targeted schemes, they show that welfare expansion along with non-redistributive policies or vice versa, are widespread political preferences among the electorate. As welfare expansion is compatible with non-redistributive policies, both parties converged to similar prowelfare positions. ${ }^{3}$

Finally, and most importantly, the main political consequence of the Great Recession in Spain has been the growth of two new parties promoting an intense anti-establishment agenda: Podemos and Ciudadanos. While electoral support for the two dominant establishment parties, PP and PSOE, often exceeded two-thirds of the vote at the national level, in many ACs their regional branches share the political space with the regionalist party family whose positions along the territorial dimension spread from autonomism to separatist nationalism (Alonso, 2012). Challengers in the past, they are now in turn being challenged by these new populist parties, which emerged after the economic crisis (Scantamburlo et al., 2018). Podemos and Ciudadanos were highly successful in their first regional contests, together achieving around $20 \%$ of the regional vote and entering almost all regional parliaments at the 2015 and 2016 regional elections. ${ }^{4}$

Both new parties campaign against old elites and claim to regenerate democracy, but substantially differ with regard to the main political cleavages that have been structuring Spanish politics, the left-right and centre-periphery conflicts. Ciudadanos can be considered as an anti-peripheral and nationalist centre-right party displaying a neoliberal type of populism (Sola \& Rendueles, 2018). Although it heavily campaigns against minority rights and

\footnotetext{
${ }^{3}$ This is related to more comprehensive studies, which show that welfare issues do not serve to differentiate between the left and right as it is frequently mentioned across the ideological spectrum (Benoit and Däubler 2014).

${ }^{4}$ While Podemos entered all regional parliaments, Ciudadanos failed to enter in Castile-La Mancha, the Canary Islands and Navarre in 2015 and in the Basque Country and Galicia in 2016.
} 
regionalist elites, it has not developed typical radical right discourses. Podemos, in turn, is apparently more pro-periphery and despite adopting a neither left nor right strategy, it is usually defined as left-wing populist party (Marcos-Marne et al., 2019).

\section{Hypotheses}

Adapting the arguments of the theoretical sections to the changing electoral supply during the Great Recession at the regional level in Spain, the present paper has two main aims: First, it explores whether the emergence of new populist challenger parties has increased party competition concerning poverty responsiveness. Second, it analyses competition between establishment and populist challenger parties. My first hypothesis is that in response to the electoral growth of new populist parties in the aftermath of the Great Recession, party competition in Spanish regions will revolve more strongly around the appeal to low-income voters. To be precise, given the higher levels of poverty and the strategic incentives of increased populist competition, I expect establishment parties, regionalist and state-wide alike, to react to competitors by being more responsive to the poor in their political agendas:

H1: The electoral growth of new populist challenger parties during the Great Recession will lead to increased attention towards poor voters in regional spaces of political competition.

Since party competition is highly determined by the broader context in which parties act, when it comes to poverty responsiveness it is likely that the political effects of the crisis in Spain (i.e. the rise of challengers) will be moderated by the structural ones (i.e. the amount of poverty). The literature has shown that the interplay of inequality and party competition influences political parties' incentives to mobilise low-income voters (Anderson \& Beramendi, 2012). While higher levels of inequality are likely to reduce these incentives in the absence of competitors, they increase them when competitors are present. Applied to the representation of the poor at regional level in Spain where the structural effects of the crisis enhanced the cross- 
regional variation in the degrees of poverty and the political effects led to similar competitive situations for establishment parties, I expect the following dynamics:

H2a: The higher the regional poverty rate, the more likely are establishment parties to decrease their attention towards poor voters in the absence of new populist challenger parties.

$\mathrm{H} 2 \mathrm{~b}$ : The higher the regional poverty rate, the more likely are establishment parties to increase their attention towards poor voters in the presence of new populist challenger parties.

Finally, I also expect variations across types of parties. First, I assume new populist parties driving competition by targeting the poor to a greater extent due to a competitive advantage. Convincing low-income citizens that they will improve their situation will be difficult for establishment parties, who have been identified as the main responsible for the crisis. At the same time, as populism cuts across the conventional political alignments so as social policy issues do particularly in the Spanish context, I expect the appeal to the poor to depend much less on parties' ideological positioning than on the new populist-establishment divide. Although the literature links the politics of inequality with the traditional left-right cleavage, representative claims towards the poor are mainly group specific appeals concerning redistribution, which can go along with neoliberal adjustments and welfare retrenchment.

H3: Concerning the appeal to poor citizens, there will be a greater difference between establishment and new populist parties than between parties of the left and the right.

\section{Data and Method}

This article uses data from the content analysis of parties' electoral manifestos to measure the substantive representation of the poor in regional elections. A great deal of literature has stressed the advantages of using election manifestos as the main source to analyse political parties' preferences (Alonso et al., 2013). Even if no voter considers them, they are a good proxy of electoral campaigns' and thus an indicator of the degree to which parties are concerned to place before the electorate policies that reflect the needs of poor people (Chaney, 2015). 
In order to measure the substantive representation of the poor at the sub-national level, I rely on the data of the Regional Manifestos Project (RMP) combined with the usage of subcategories (Horn et al., 2017). The RMP is an adaptation of the Manifesto Project's (MARPOR) methodology, developed for the analysis of multilevel contexts (Alonso et al., 2013). The RMP codes quasi-sentences (defined as argument) of regional party manifestos grouping them into a set of policy categories to determine how important an issue is for a party. For this analysis the most relevant categories are c503 (equality: positive) and c504 (welfare state expansion), as almost all references towards the poor are coded under those two items. Yet, as they comprise various connotations of equality and welfare and the recipients belong to different societal groups, an analysis using those categories would be misleading. I therefore refine the two items through sub-categories identifying references that directly address the poor as a social group using a similar procedure as in Horn et al. (2017). More concretely, each quasi-sentence belonging to these categories has been filtered and sub-coded in order to capture explicit references addressing the poor and policies aiming at improving their situation. Table A1 in the appendix displays examples of the sub-coding procedure.

The main empirical indicators throughout the article are salience scores calculated as the percentage of quasi-sentences in a manifesto assigned to the relevant sub-categories. While the theoretical range of poverty issue salience goes from 0 to 100 , empirically it goes from 0 to 5.82 (Podemos Canary Islands in 2015). This means that the highest attention that any party has ever devoted to the poor between 2007 and 2017 is almost 6\% percent of a manifesto's quasi-sentences. With 2.17 (SD 1.26), the mean saliency is much lower. Altogether, 163 electoral manifestos of the most relevant political parties in all 17 Spanish ACs have been subcoded. The data include 10 regionalist and 4 state-wide parties, 2 of them being new populist challenger parties. Given the relatively smaller size of regionalist parties, I selected parties that 
have always been elected to the regional assembly in the period under study with at least $5 \%$ vote share. Table A2 in the appendix shows the full list of parties and regions in the dataset.

[Figure 1 about here]

Figure 1 takes a closer look at the representation of the poor in Spanish state-wide and regionalist parties' manifestos $(N=163)$. In examining this figure, two patterns are readily apparent. First, new populist challengers are clearly those parties claiming to represent the poor to a higher degree. With a mean of 4.2 , the party having the strongest focus on the poor is Podemos followed by Ciudadanos who talks about the poor in $3.2 \%$ of its manifestos. The establishment parties have more similar attention rates, with the PSOE and the regionalist parties being more attentive towards the poor than the PP. Second, there is an important variance within parties. While the PSOE is the party with the greatest distribution, Ciudadanos displays more similar attention rates. Besides the differences between parties, these patterns suggest high adjustment to the regional political contexts.

As I am, first of all, interested in how establishment parties at the regional level respond to populist challengers I look at issue emphasis for all establishment parties in 17 Spanish ACs in the elections since the unfolding of the Great Recession. My unit of analysis is the individual party and to focus on establishment parties' responses I omit new populist parties from the analysis. There are two main explanatory variables. The first one is a dichotomous variable that indicates the presence (1) or absence (0) of a populist challenger party that emerged in the aftermath of the economic crisis. The second main explanatory variable constitutes the regional poverty rate, which aims at capturing if poverty responsiveness varies with the degree of poverty. This variable refers to the ratio of the number of people whose income falls below the 
poverty line and is calculated taking $60 \%$ of the median annual income per consumption unit. ${ }^{5}$ Acknowledging the no doubt controversial nature of a relative definition of poverty, as it depends on the degree of development of the society under study, such a measure can be a useful tool for the analysis of a single case in a specific period of time.

With an eye to previous research, I take into account some additional controls. I first include the regional population density, which is calculated according to the population by $\mathrm{km}^{2}$. This variable aims at tackling the rural-urban divide, given that the location of poverty may differentially influence parties' responsiveness (Jusko, 2008). Second, I control for a party's government status indicating whether the party was part of the regional government at the time of writing the manifesto. Contrary to opposition parties, government parties are likely to be more often forced to respond to the 'party-system agenda' (Green-Pedersen \& Mortensen, 2010). As a third control, the vote share in the last regional election accounts for the influence of party size. To increase their vote share, smaller parties are more likely to increase their emphasis on poverty. Fourth, I include party positioning on the left-right scale using the RILE variable developed by the RMP team (Alonso et al., 2013). As the poor constitute their "natural constituency' (Anderson \& Beramendi, 2012), I expect higher attention among left parties. Finally, a dummy identifying the historical nationalities (Catalonia, the Basque Country and Galicia) accounts for the different regional electoral calendars and political dynamics (Leonisio \& Scantamburlo, 2019).

To evaluate $\mathrm{H} 3$, a second set of models presented in the analysis are estimated using a different subsample comparing only those elections where populist parties entered competition $(N=74)$ and including dichotomous variables differentiating between populist vs. establishment and between left vs. right party groups as additional explanatory variables. While the classification of challenger and establishment parties is straightforward, left and right parties

\footnotetext{
${ }^{5}$ I rely on data from the Spanish national statistical institute (INE).
} 
need to be identified. For that purpose, I use a similar approach as Hobolt and de Vries (2015) comparing the average RILE scores for each party with the party system mean using weighted party values (by vote share). Since negative values refer to leftist positions, parties with mean values below the party system mean are coded as left.

For each set of hypotheses, different models are estimated with ordinary least squares. In order to avoid serial correlation, the models include a lagged dependent variable. The lagged dependent variable also has a substantial meaning given that parties' manifestos are not written from scratch. The use of panel corrected standard errors (Beck \& Katz, 1995) instead is inappropriate because the number of parties exceeds the number of time units. Nonetheless, all models are estimated with robust standard errors clustered by party within region.

\section{Analysis and Results}

In the previous section, I briefly introduced the programmatic agenda of the main parties acting in Spanish ACs and showing the differences concerning the representation of the poor. In this section, I am first going to analyse the responses of establishment parties to new competitors in the respective regions. I then move on to a more detailed analysis of different party groups.

\section{Representing the Poor: Responding to Challengers}

According to H1, I should see an increase in the representation of the poor in regional political spaces with the emergence of new challengers. An initial visualisation in Figure 2 and Table A4 in the appendix shows the evolution of representative claims towards the poor in regional political spaces for two electoral periods marked by the beginning of the crisis. The salience scores represent average values for all parties in the region, excluding new challenger parties. Out of 15 regions, $8(47 \%)$ saw an u-shaped evolution, with an initial decrease in salience at the first crisis election, followed by a substantive increase in the second post-crisis electoral 
cycle. In the remaining 9 regions a constant increase since 2008 can be observed. Only three regions (18\%) saw issue attention towards the poor increase more at the first post-crisis election.

[Figure 2 about here]

The salience analysis over time seem to provide evidence for $\mathrm{H} 1$. While in almost the half of ACs salience scores even decreased at the first post-crisis election, when challenged by a new populist competitor they increase in all regions. Indeed the mean differences between periods are statistically significant only between the first and the second post-crisis elections $(\mathrm{p}<0.01)$. Looking at issue consistency, which is measured as the coefficient of variation ${ }^{6}$ of the issue's salience scores in party manifestos (Alonso, 2012), a first decrease followed by an increase can be observed between electoral periods (pre-crisis: 0.35 ; 1st_post: $0.49 ; 2$ nd_post: 0.25 ). This again shows that major changes occurred with the emergence of challengers.

In order to delve further into these findings Table 1 presents the results of two OLS regression models. Model 1 is a basic model, with the main independent variables and controls. Model 2 includes the interaction of interest. Overall, in terms of explaining the extent to which establishment parties respond to the populist challenge, there is again strong support for $\mathrm{H} 1$ : establishment parties' attention towards the poor significantly increases with the presence of new populist challenger parties. Concerning the main structural variable of interest, the poverty rate in a region does not play a decisive role for the representation of the poor in regional party manifestos. On the other hand, establishment parties seem to increase their attention in regions with a higher population density, showing that the representative claims towards the poor are stronger in more urban regions than in rural ones. In terms of the other control variables, the

\footnotetext{
${ }^{6}$ The coefficient of variation is the standard deviation divided by the mean and allows knowing if a sample is dispersed or concentrated. If the variation ratio is $>0.30$, the data is considered to be dispersed. If it is $<0.30$, the data is concentrated around the mean.
} 
estimates indicate that left-wing parties display higher salience scores than right-wing parties, as indicated by the negative coefficient of the RILE variable. While the lagged dependent variable is strongly significant, which shows that parties base their manifestos on previous ones, the remaining variables do not reach standard levels of statistical significance.

\section{[Table 1 about here]}

What about the interplay between structural and political factors? Following the theoretical lines of reasoning Model 2 includes an interaction between those regional elections, which saw a new populist challenger parties emerge and the regional poverty rate. The interaction term is statistically significant and positive. Additionally, according to the estimated coefficients presented in Model 2, the significant positive effect of the interaction term compensates the negative effect of the variable that identifies the regional poverty rate. These effects of the poverty rate on party issue attention towards the poor can be interpreted as its independent influence when the interaction term is zero - that is, when there is no populist challenger party in the region. Consequently higher levels of poverty lead to lower attention towards the poor in the absence of challengers, while the opposite seems to be the case in the presence of a challenger party. To help interpret correctly the coefficients of the interaction terms Figure 3 shows the corresponding average marginal effects (AMEs). Concerning the regional poverty rate, the effect for the absence of populist challengers is as expected negative, whereas in the presence of challengers it is positive. The significance level for the latter are however not as strong as for the former. All in all these dynamics provide evidence for the conditional hypotheses $\mathrm{H} 2 \mathrm{a}$ and $\mathrm{H} 2 \mathrm{~b}{ }^{7}$

\footnotetext{
${ }^{7}$ The results are robust to the inclusion of party dummies, the usage of a different poverty measure (the AROPE indicator), the exclusion of outlier cases and control variables.
} 
[Figure 3 about here]

To underline the substantive differences between the absence and presence of challenger parties, Figure 4 presents the linear predictions on establishment parties' poverty responsiveness depending on the regional poverty rate. The predictions are plotted for various levels of poverty and are statistically significant. If the regional poverty rate is low, we see only slight differences between establishment parties facing or not facing populist challengers. As indicated by the results in Table 1 and Figure 3 this difference significantly increases to almost 1.9 scale points when the poverty rate is over 35\% (Andalusia and the Canary Islands in 2015). These values can be compared to the empirical range of the dependent variable, which is about 5.2. According to the expectations of the literature, higher levels of poverty induce establishment parties to ignore the poor in their political offering. The picture however is completely different when new challenger parties are present in the political space. Combined with increasing populist competition higher levels of poverty create incentives for political parties to be more attentive to the poor.

[Figure 4 about here]

\section{Representing the Poor: Establishment Parties vs. New Populist Challengers}

According to $\mathrm{H} 3$, populist challenger parties should represent poor citizens in their programmatic agenda to a greater degree than establishment parties and this new divide should explain the attention towards poor citizens better than traditional left-right positioning. The idea behind that is that populism as an answer to ineffectual representation cuts across the ideological left-right conflict. While Figure 1 has already shown the difference between establishment and populist parties, Table 1 has shown that left-wing establishment parties pay 
more attention to poor citizens than right-wing ones. In order to compare both political divides, Table 2 includes a different subsample with only those regional elections where establishment and populist challengers compete with each other. Using dichotomous variables for the various party groups Model 1 looks at the differences between left and right parties and Model 2 between establishment parties and new challengers. Estimating two different models allows comparing both effects and the explained variance.

[Table 2 about here]

Model 1 again confirms that in their political offering left-wing parties pay attention to the poor to a higher degree then right-wing parties. The Left party variable has a positive and statistically significant effect on poverty responsiveness compared to the reference category (i.e. Right party). This finding is consistent with long-standing historical patterns of electoral democracies where voters with lower incomes constitute the most natural constituency of left parties (Anderson \& Beramendi, 2012). In Model 2, however, the same pattern can be observed when differentiating between populist challengers and establishment parties. A comparison of the two models shows that the coefficient for populist parties is substantively larger and almost doubling the positive effect of the one concerning left parties. Moreover, although the model fit in both regressions is not very good, R-square substantially increases in Model 2.

With respect to the control variables, one finding should be mentioned. While the significant effect of poverty rate disappears in Model 2, population density is positively associated to poverty responsiveness also for this subsample. Indeed, urban and rural poverty differ according to the informal safety nets that both situations may encounter, making poor economic circumstances particularly difficult to handle in urban areas (Resnick, 2012). While higher issue attention in urban areas may be explained on the basis of a similar dynamic concerning the 
degrees of poverty, the link between poverty responsiveness and poverty location (Jusko 2008) has yet to be to be fully explored.

\section{Concluding Remarks}

Looking at the case of Spain during the Great Recession, the main objective of this article was to provide an answer to two interrelated questions. First, whether and how the emergence of new populist challengers (after 2008) has increased establishment parties' issue attention towards poor citizens, and second, whether the difference between the new populistestablishment divide explains parties' issue attention towards the poor better then left-right positioning. The relevance of these questions is twofold: on the one hand, it fills a gap in the literature on populism and its relation with representation of excluded citizens; on the other, it looks at the responses of the political establishment to the challenges brought up by new actors.

First, we have seen that establishment parties have reacted to competitors by increasing the attention dedicated to issues concerning poverty in their political agenda. Although they are certainly not the ones dominating the debate, there is no doubt that they have broken into the party system agenda more strongly than in previous elections. The analysis shows that in the aftermath of the Great Recession establishment parties were especially unresponsive to the needs of low-income citizens in those regions where the crisis had the strongest effects. Instead, it is mainly in these regions that they increased their attention towards the poor after the emergence of new competitors. Second, we have seen that populist parties represent the poor to a greater degree in their political agenda then establishment parties and that they do so irrespective of their left-right positioning. The significant differences between the left and the right, however, suggest that concerning the inclusion of low-income citizens the traditional ideological divides continue to be highly relevant.

Therefore, this paper finds confirmation for the corrective potential of populism (Kaltwasser, 2012) and the closing of a representative gap. Given the unique character of the 
Spanish case, however, the findings can only partly be generalised to other cases of Southern Europe, such as Italy or Greece, where the first post-crisis decade saw mainly parties from the 'left' challenge old political elites and the cultural-identitarian divide did not reach the same relevance as in North Western Europe. The transformation of the Northern League into a statewide nationalist party and even the electoral growth of the party VOX in Spain confirm that Southern Europe is not immune to the growth of the populist radical right. Testing the populist representation hypothesis for this group of parties taking into account the concept of welfare chauvinism remains a task for further exploration. 


\section{References}

Alonso, S. (2012). Challenging the state: Devolution and the battle for partisan credibility. Oxford: Oxford University Press.

Alonso, S., Gómez, B., \& Cabeza, L. (2013). Measuring centre-periphery preferences: The Regional Manifestos Project. Regional \& Federal Studies, 23(2), 189-211.

Anderson, C. J., \& Beramendi, P. (2012). Left parties, poor voters, and electoral participation in advanced industrial societies. Comparative Political Studies 45(6): 714-746.

Bartels, L. (2008). Unequal democracy: The political economy of the new gilded age. New York: Russell Sage Foundation.

Beck, N., \& Katz, J. N. (1995). What to do (and not to do) with time-series-cross-section data in comparative politics. American Political Science Review, 89 (3), 634-647.

Benoit, K., \& Däubler, T. (2014). Putting text in context: How to estimate better left-right positions by scaling party manifesto data using item response theory. 'Mapping policy preferences from texts' conference, Berlin.

Bornschier, S. (2017). Populist mobilization across time and space: An introduction. Swiss Political Science Review, 23(4), 301-312.

Budge, I., \& Farlie, D. J. (1983). Party competition: Selective emphasis or direct confrontation? An alternative view with data. In Western European Party Systems, edited by Daalder, H. and Mair, P. London: Sage, 267-271.

Caramani, D. (2017). Will vs. Reason: The populist and technocratic forms of political representation and their critique to party government. American Political Science Review, 111(1), 54-67.

Celis, K., Childs, S., Kantola, J., \& Krook, M.L. (2008). Rethinking women's substantive representation. Representation, 44(2), 99-110.

Chaney, P. (2015). Manifesto discourse and the substantive representation of ethnic minorities: analysis of UK state-wide and meso elections, 1964-2011. Parliamentary Affairs, 68(1), $154-181$.

Ciudadanos Castilla y León. (2015). Castilla y León pide cambio. Programa elecciones autonómicas 2015.

Dahl, R. (1971). Polyarchy: participation and opposition. New Haven: Yale University Press.

EAPN. (2018). State of poverty. Follow up on the indicator on poverty and social exclusion 2008-2017 (8th Report). Retrieved from https://www.eapn.es/estadodepobreza/index.php

Elsässer, L., Hense, S., \& Schäfer, A. (2017). „Dem Deutschen Volke“? Die ungleiche Responsivität des Bundestags. Zeitschrift für Politikwissenschaft, 27(2), 161-180.

Fernández-Albertos, J., \& Manzano, D. (2012). The lack of partisan conflict over the welfare state in Spain. South European Society and Politics, 17 (3), 427-447.

Gómez, B., \& Trujillo, M. (2011). Los excluidos también pueden votar: abstención y exclusión social en España. Documento de trabajo 169. Madrid: Fundación Alternativas.

Green-Pedersen, C., \& Mortensen, P. (2010). Who sets the agenda and who responds to it in the Danish parliament? A new model of issue competition and agenda-setting. European Journal of Political Research, 49(2), 257-281. 
Hernández, E., \& Kriesi H. (2016). The electoral consequences of the financial and economic crisis in Europe'. European Journal of Political Research, 55(2), 203-224.

Hobolt, S.B., \& De Vries, C. (2015). Issue entrepreneurship and multiparty competition. Comparative Political Studies, 48(9), 1159-1185.

Horn, A., Kevins, A., Jensen, C., \& Van Kersbergen, K. (2017). Research note: peeping at the corpus - What is really going on behind the equality and welfare items of the Manifesto Project? Journal of European Social Policy, 27(5), 403-416.

Huber, R. A., \& Ruth, S. P. (2017). Mind the gap! Populism, participation and representation in Europe. Swiss Political Science Review, 23(4), 462 - 484.

Jusko, K. L. (2008). The political representation of the poor (Dissertation University of Michigan).

Kaltwasser, C.R. (2012) The ambivalence of populism: Threat and corrective for democracy. Democratization, 19(2), 184-208.

Kriesi, H. (2014). The populist challenge. West European Politics, 37(2), 361-378.

Laclau, E. (2005). On populist reason. London: Verso.

Leonisio, R., \& Scantamburlo, M. (2019). La competición política en el País Vasco, 1980-2016. El equilibrio entre la dimensión económica y la nacionalista. In En busca del poder territorial. Cuatro décadas de elecciones autonómicas en España, edited by Gómez, B., Alonso, S. and Cabeza, L. Madrid: CiS, 255-279.

Meguid, B. (2008). Party Competition between unequals. Cambridge: Cambridge University Press.

Marcos-Marne, H., Plaza-Colodro, C., \& Freyburg T. (2019). Who votes for new parties? Economic voting, political ideology and populist attitudes, West European Politics (early view).

Mair, Peter (2013). Ruling the void: The hollowing of western democracy. London: Verso.

Mudde, C. (2004). The populist zeitgeist. Government and Opposition, 39(4), 541-563.

Mudde, C., Kaltwasser, C. R. (2013). Exclusionary vs. inclusionary populism: comparing contemporary Europe and Latin America. Government and Opposition, 48 (2), 147-174.

Pitkin, H. F. (1967). The concept of representation. Berkeley, CA: University of California Press.

Podemos Castilla y León. (2015). Medidas para el cambio en Castilla y León. Programa elecciones autonómicas 2015.

Pontusson, J., \& Rueda, D. (2010). The politics of inequality: voter mobilization and left parties in advanced industrial states. Comparative Political Studies, 43(6), 675-705.

Resnick, D. (2012). Opposition parties and the urban poor in African democracies. Comparative Political Studies, 45(11), 1351-1378.

Rigby, E., \& Wright, G. D. (2013). Political parties and representation of the poor in the American states. American Journal of Political Science, 57(3), 552-565.

Roberts, K. M. (1995). Neoliberalism and the transformation of populism in Latin America: the Peruvian case. World Politics 48(1), 82-116. 
Roberts, K. M. (2016). Populism and political representation, in The Oxford handbook of the politics of development edited by Lancaster C. and van de Walle, N. New York: Oxford University Press, 517-536.

Ruth, S. P., \& Hawkins, K. (2017). Populism and democratic representation in Latin America, In Handbook on political populism, edited by Heinisch, R., Mazzoleni, O. and HoltzBacha, C. Baden-Baden: Nomos, 255-273.

Saward, M. (2006). The representative claim. Contemporary Political Theory, 5(3), 297-318.

Scantamburlo, M., Alonso, A., \& Gómez, B. (2018). Democratic regeneration in European peripheral regions: New politics for the territory? West European Politics, 41(2), 615-639.

Schäfer, A. (2018). The poor representation of the poor. In Destabilizing orders Understanding the consequences of neoliberalism, edited by Andersson, J. and Godechot, O. Paris: MaxPo Discussion Paper 18/1, 86-89.

Sola, J., \& Rendueles, C. (2018) Podemos, the upheaval of Spanish politics and the challenge of populism. Journal of Contemporary European Studies, 26(1), 99-116.

Solt, F. (2008). Economic inequality and democratic political engagement. American Journal of Political Science, 52(1), 48-60.

Vampa, D. (2016). The Regional politics of welfare in Italy, Spain and Great Britain. Basingstoke: Palgrave Macmillan. 


\section{Tables}

Table 1. The impact of challenger parties on the representation of the poor

\begin{tabular}{|l|l|l|l|l|}
\hline & \multicolumn{2}{|c|}{ Model 1 } & \multicolumn{2}{c|}{ Model 2 } \\
\hline & Coeff. & SE & Coeff. & SE \\
\hline Challenger & $0.978^{* * *}$ & $(0.184)$ & 0.006 & $(0.389)$ \\
\hline Poverty rate & 0.0002 & $(0.008)$ & $-0.029 * *$ & $(0.012)$ \\
\hline Poverty rate x Challenger & & & $0.051^{* * *}$ & $(0.017)$ \\
\hline Population density & $0.001^{* * *}$ & $(0.0003)$ & $0.001 * * *$ & $(0.0003)$ \\
\hline Incumbency & 0.038 & $(0.188)$ & 0.010 & $(0.185)$ \\
\hline Party size & -0.006 & $(0.006)$ & -0.006 & $(0.006)$ \\
\hline Rile position & $-0.026^{* *}$ & $(0.010)$ & $-0.026 * *$ & $(0.010)$ \\
\hline Historical nationality & -0.126 & $(0.203)$ & -0.160 & $(0.196)$ \\
\hline Party issue attention $(t-1)$ & $0.444 * * *$ & $(0.127)$ & $0.491^{* * *}$ & $(0.119)$ \\
\hline Constant & $0.950^{* * *}$ & $(0.317)$ & $1.479 * * *$ & $(0.335)$ \\
\hline $\mathrm{N}$ & 88 & & 88 & \\
\hline R2 & 0.523 & & 0.557 & \\
\hline
\end{tabular}

DV, Poverty issue attention (percentage of quasi-sentences that is devoted to the issue of poverty in regional election manifestos). ${ }^{*} p<0.1 ; * * p<0.05 ; * * * p 0.01$ (standard errors in parenthesis). 
Table 2. Representation of the poor according to different party groups

\begin{tabular}{|l|c|c|c|c|}
\hline & \multicolumn{2}{|c|}{ Model 1 } & \multicolumn{2}{c|}{ Model 2 } \\
\hline & Coeff. & SE & Coeff. & SE \\
\hline Left party & $0.663^{* * *}$ & $(0.232)$ & & \\
\hline Populist party & & & $1.163^{* * *}$ & $(0.239)$ \\
\hline Poverty rate & $0.023^{*}$ & $(0.012)$ & 0.017 & $(0.012)$ \\
\hline Population density & $0.001^{* * *}$ & $(0.0004)$ & $0.001^{* *}$ & $(0.0006)$ \\
\hline Incumbency & -0.259 & $(0.313)$ & -0.365 & $(0.291)$ \\
\hline Party size & -0.017 & $(0.015)$ & 0.013 & $(0.014)$ \\
\hline Historical nationality & -0.140 & $(0.228)$ & 0.147 & $(0.192)$ \\
\hline Constant & $2.519^{* * *}$ & $(0.411)$ & $1.875^{* * *}$ & $(0.400)$ \\
\hline $\mathrm{N}$ & 74 & & 74 & \\
\hline R2 & 0.270 & & 0.359 & \\
\hline
\end{tabular}

DV, Poverty issue attention (percentage of quasi-sentences that is devoted to the issue of poverty in regional election manifestos). ${ }^{*} \mathrm{p}<0.1 ; * * \mathrm{p}<0.05 ; * * * \mathrm{p}<0.01$ (standard errors in parenthesis). 


\section{Figures}

Figure 1. Poverty issue attention of different parties

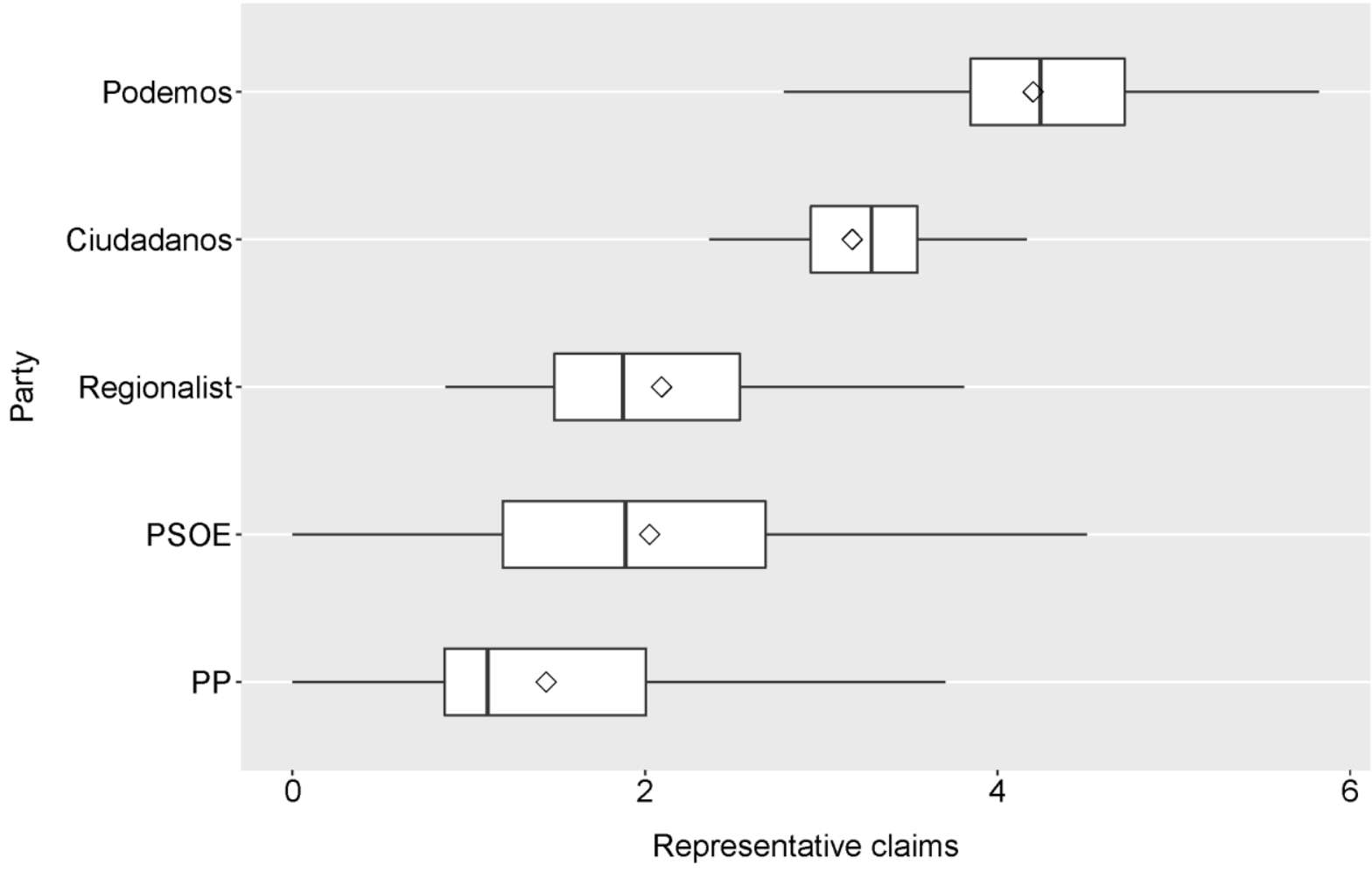

Note: The boxplots represent the percentage of manifesto space that is devoted to the issue of poverty (representative claims) in regional election manifestos. Squares indicate mean values. 
Figure 2. Change in poverty issue attention by region (pre- and post-crisis)

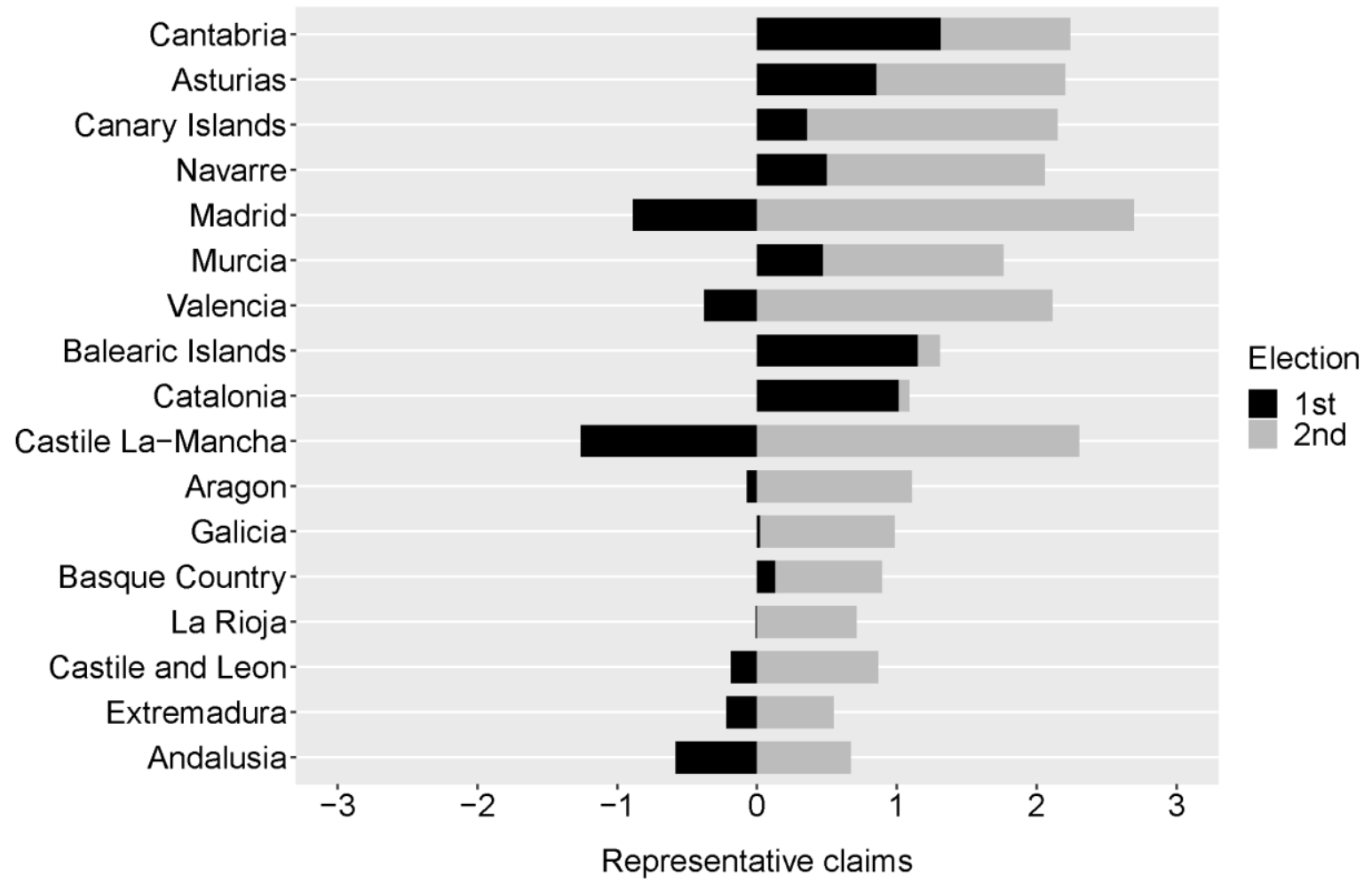

Note: The bars represent the percentage of manifesto space that is devoted to the issue of poverty (representative claims) in regional election manifestos. 
Figure 3. Marginal effects plot

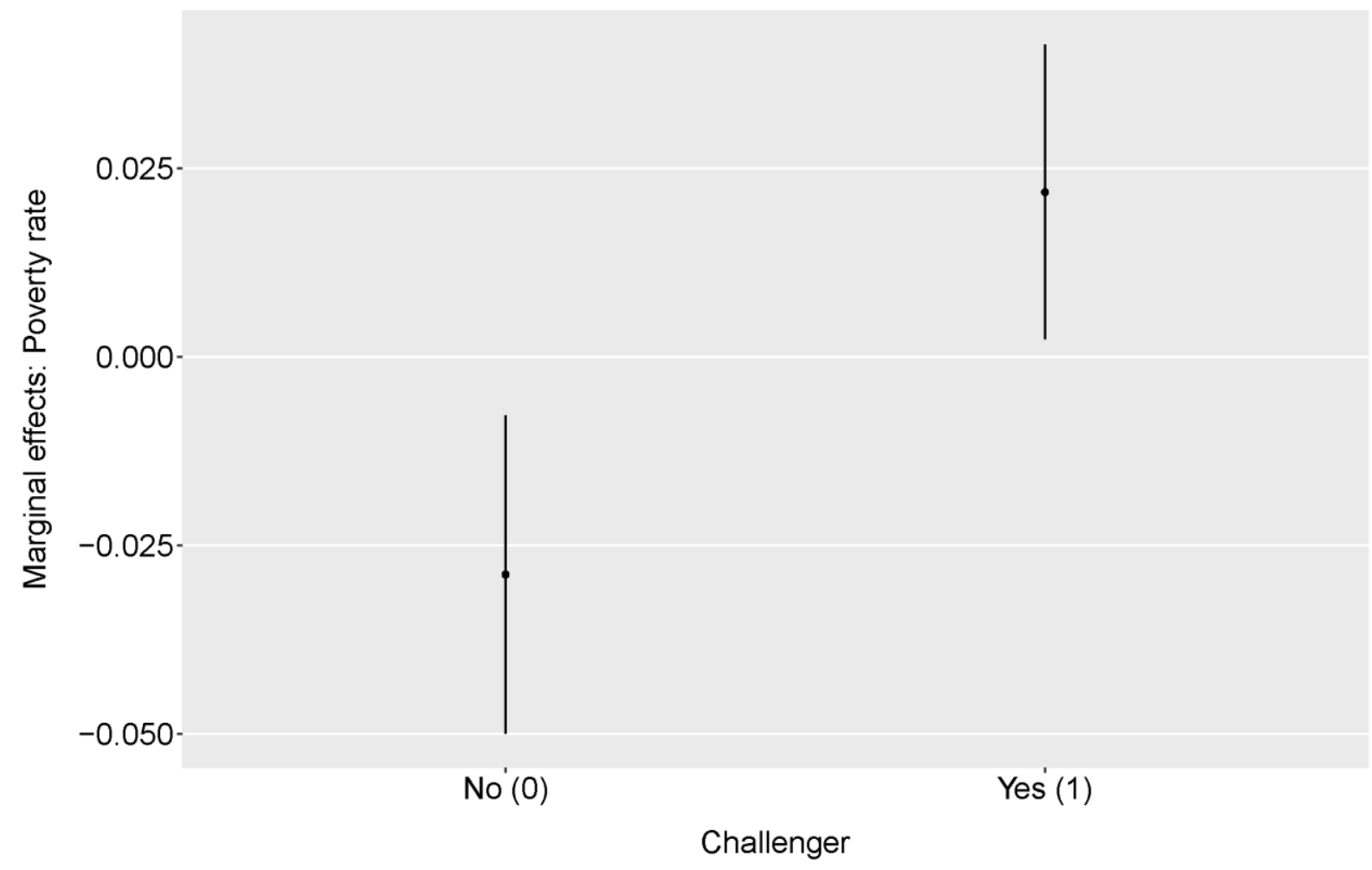

Note: The value for the absence of challengers is $-0.029(\mathrm{p}=0.016)$ and the presence of challengers $0.022(\mathrm{p}=0.050)$. Error bars give $90 \%$ confidence intervals. 
Figure 4. Linear prediction of poverty issue attention

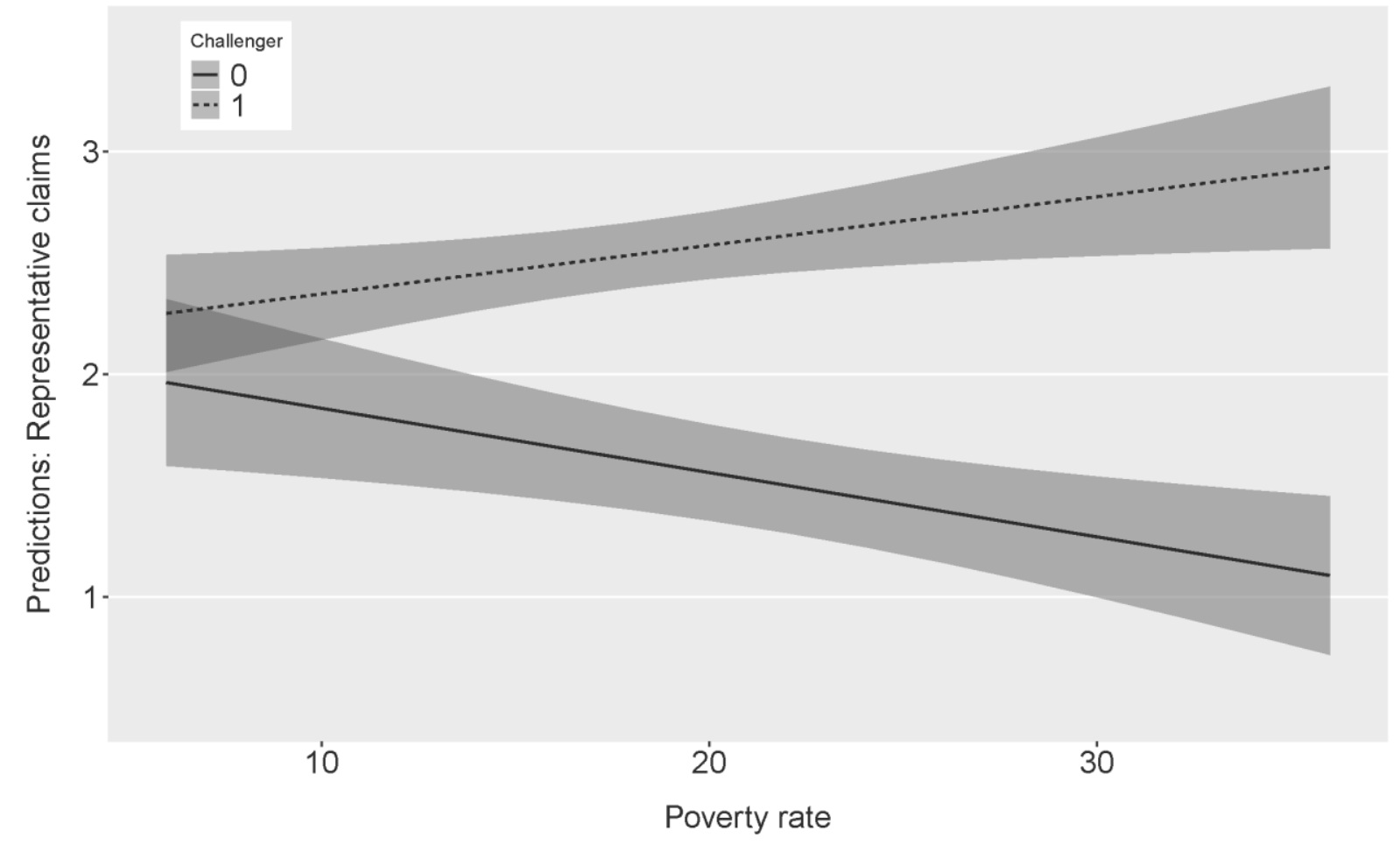

Note: The dotted line indicates the presence (1) and the solid line the absence (0) of challengers. Error bars give $90 \%$ confidence intervals. 


\section{Appendix}

Table A1. Examples of the sub-coding of RMP equality and welfare codes

\begin{tabular}{|c|c|}
\hline RMP Code & Description \\
\hline \multirow[t]{2}{*}{ c503 } & Equality positive \\
\hline & $\begin{array}{l}\text { Concept of social justice and the need for fair treatment of all people. This may include } \\
\text { the following: Special protection for underprivileged social groups; Removal of class } \\
\text { barriers; Need for fair distribution of resources; The end of discrimination. }\end{array}$ \\
\hline Subcode: & Example sentence: \\
\hline c503_0 & $\begin{array}{l}\text { Ciudadanos reaffirm their defence of the welfare state as a guarantee of equal } \\
\text { opportunities (Ciudadanos Castilla y León 2015). }\end{array}$ \\
\hline c503_1 & $\begin{array}{l}\text { We will deploy social prevention policy actions aimed at the most vulnerable } \\
\text { segments of the population and will focus on the most common causes of social } \\
\text { exclusion (Ciudadanos Castilla y León 2015). }\end{array}$ \\
\hline \multirow[t]{2}{*}{$\mathbf{c 5 0 4}$} & Welfare state expansion \\
\hline & $\begin{array}{l}\text { Favourable mentions of need to introduce maintain or expand any public social service } \\
\text { or social security scheme. This includes, for example, government funding of the } \\
\text { following: Healthcare; Childcare; Elder care and pensions; Social housing. }\end{array}$ \\
\hline \multirow{2}{*}{$\begin{array}{r}\text { Subcode: } \\
\text { c504_0 }\end{array}$} & Example sentence: \\
\hline & $\begin{array}{l}\text { Restoration of public character in the management of social services and } \\
\text { subordination of these services under the control of citizens (Podemos Castilla y } \\
\text { León 2015). }\end{array}$ \\
\hline c504_1 & $\begin{array}{l}\text { Public information on the current plans on aid for social rents, mortgage payments } \\
\text { and social benefits for families with limited resources and at risk of marginalisation } \\
\text { and social exclusion (Podemos Castilla y León 2015). }\end{array}$ \\
\hline & uasi-sentences belonging to equality and welfare expansion that include explici \\
\hline
\end{tabular}


Table A2. Mean poverty issue attention by party and region (new populist parties in bold)

By Party

\begin{tabular}{|l|c|c|c|c|c|}
\hline \multirow{2}{*}{ Party } & \multirow{2}{*}{$\mathrm{N}$} & \multicolumn{4}{|c|}{ Poverty Issue Salience } \\
\cline { 3 - 6 } & & Mean & SD & Min & Max \\
\hline Spanish Socialist Workers Party (PSOE) & 51 & 2.03 & 1.14 & 0 & 5.20 \\
\hline Popular Party (PP) & 51 & 1.44 & 0.88 & 0 & 3.70 \\
\hline Podemos & 17 & 4.20 & 0.91 & 2.43 & 5.82 \\
\hline Ciudadanos (C's) & 13 & 3.18 & 0.67 & 1.60 & 4.17 \\
\hline Aragonese Party (PAR) & 3 & 1.12 & 0.35 & 0.87 & 1.52 \\
\hline Socialist Party of Majorca (PSM/Més) & 3 & 1.47 & 0.35 & 1.23 & 1.88 \\
\hline Basque Nationalist Party (EAJ) & 3 & 2.35 & 0.32 & 1.99 & 2.61 \\
\hline Basque Country Unite (EHB) & 4 & 2.63 & 1.02 & 1.62 & 3.57 \\
\hline Regionalist Party of Cantabria (PRC) & 3 & 3.12 & 1.30 & 1.7 & 4.24 \\
\hline Canarian Coalition (CC) & 3 & 1.83 & 0.68 & 1.41 & 2.61 \\
\hline Navarre Yes (NaBai/GeBai) & 3 & 1.99 & 0.79 & 1.38 & 2.88 \\
\hline Convergence and Union (CiU/JxC) & 3 & 1.68 & 0.52 & 1.12 & 2.14 \\
\hline Republican Left of Catalonia (ERC) & 3 & 2.73 & 0.94 & 2.14 & 3.81 \\
\hline Galician Nationalist Bloc (BNG) & 3 & 1.84 & 0.54 & 1.50 & 2.46 \\
\hline
\end{tabular}

\section{By Region}

\begin{tabular}{|l|c|c|c|c|c|}
\hline \multirow{2}{*}{ Region } & \multirow{2}{*}{$\mathrm{N}$} & \multicolumn{4}{|c|}{ Poverty Issue Salience } \\
\cline { 5 - 7 } & & Mean & SD & Min & Max \\
\hline Andalusia & 8 & 2.46 & 1.23 & 1.02 & 4.74 \\
\hline Aragon & 11 & 1.64 & 1.41 & 0.39 & 4.72 \\
\hline Asturias & 8 & 1.98 & 1.34 & 0.18 & 3.63 \\
\hline Cantabria & 11 & 2.07 & 1.22 & 0.23 & 4.24 \\
\hline Castile and Leon & 8 & 1.86 & 1.22 & 0.74 & 4.17 \\
\hline Castile-La Mancha & 7 & 1.88 & 2.00 & 0 & 5.71 \\
\hline Canary Islands & 10 & 2.33 & 1.61 & 0.81 & 5.82 \\
\hline Catalonia & 15 & 2.60 & 1.35 & 0.62 & 5.20 \\
\hline Extremadura & 8 & 1.66 & 0.93 & 0.91 & 3.28 \\
\hline Galicia & 10 & 1.91 & 0.85 & 1.03 & 3.85 \\
\hline Balearic Islands & 11 & 2.30 & 1.06 & 0.92 & 4.04 \\
\hline Murcia & 8 & 2.70 & 1.24 & 1.18 & 4.56 \\
\hline Madrid & 8 & 2.87 & 1.23 & 1.20 & 4.51 \\
\hline Navarre & 12 & 2.15 & 1.27 & 0.70 & 4.80 \\
\hline Basque Country & 12 & 2.17 & 0.98 & 0.87 & 4.04 \\
\hline La Rioja & 8 & 2.16 & 1.22 & 0.85 & 4.50 \\
\hline Valencia & 8 & 2.01 & 1.41 & 0.39 & 4.45 \\
\hline
\end{tabular}


Table A3. Descriptive statistics

Ad Table 1 (Model 1 and 2)

\begin{tabular}{|l|c|c|c|c|c|}
\hline & Obs. & Mean & Std. Dev. & Min & Max \\
\hline Poverty issue salience & 133 & 1.816 & 1.026 & 0 & 5.2 \\
\hline Challenger Party & 133 & 0.338 & 0.475 & 0 & 1 \\
\hline Poverty rate & 133 & 18.669 & 7.904 & 5.9 & 35.4 \\
\hline Population density & 133 & 166.443 & 165.301 & 26 & 800 \\
\hline Government party & 133 & 0.466 & 0.501 & 0 & 1 \\
\hline Vote share & 133 & 33.406 & 13.557 & 7.21 & 60.09 \\
\hline RILE position & 133 & -0.952 & 7.057 & -24.32 & 18.86 \\
\hline Historical region & 133 & 0.241 & 0.429 & 0 & 1 \\
\hline
\end{tabular}

Ad Table 2 (Model 1 and 2)

\begin{tabular}{|l|c|c|c|c|c|}
\hline & Obs. & Mean & Std. Dev. & Min & Max \\
\hline Poverty issue salience & 74 & 3.096 & 1.064 & 1.06 & 5.82 \\
\hline Left party & 74 & 0.541 & 0.502 & 0 & 1 \\
\hline Populist party & 74 & 0.392 & 0.492 & 0 & 1 \\
\hline Poverty rate & 74 & 19.458 & 8.471 & 9 & 35.4 \\
\hline Population density & 74 & 167.797 & 177.524 & 26 & 800 \\
\hline Government party & 74 & 0.258 & 0.440 & 0 & 1 \\
\hline Vote share & 74 & 19.936 & 10.450 & 4.26 & 48.3 \\
\hline Historical region & 74 & 0.311 & 0.466 & 0 & 1 \\
\hline
\end{tabular}


Table A4. Evolution of poverty issue attention in the space of political competition by region (pre- and post-crisis; standard deviations in brackets)

\begin{tabular}{|l|l|l|l|}
\hline Region & Pre-crisis & 1st_post-crisis & 2nd_post-crisis \\
\hline Andalusia & $1.90(0.47)$ & $1.32(0.42)$ & $2.47(0.81)$ \\
\hline Aragon & $0.73(0.21)$ & $0.66(0.25)$ & $1.77(0.22)$ \\
\hline Asturias & $0.44(0.37)$ & $1.30(0.92)$ & $2.65(0.58)$ \\
\hline Balearic Islands & $1.36(0.52)$ & $2.51(1.06)$ & $2.67(0.91)$ \\
\hline Canary Islands & $1.08(0.30)$ & $1.44(0.39)$ & $3.31(0.61)$ \\
\hline Cantabria & $0.81(0.78)$ & $2.13(1.36)$ & $3.05(1.04)$ \\
\hline Castile-La Mancha & $1.26(0.69)$ & $0.00(0.00)$ & $2.48(0.57)$ \\
\hline Castile and Leon & $1.09(0.41)$ & $0.91(0.24)$ & $1.77(0.50)$ \\
\hline Catalonia & $1.70(1.03)$ & $2.72(1.71)$ & $2.79(1.51)$ \\
\hline Extremadura & $1.15(0.30)$ & $0.93(0.03)$ & $1.52(0.65)$ \\
\hline Galicia & $1.36(0.26)$ & $1.38(0.30)$ & $2.35(0.14)$ \\
\hline La Rioja & $1.33(0.67)$ & $1.32(0.41)$ & $2.03(0.13)$ \\
\hline Madrid & $2.30(0.37)$ & $1.41(0.29)$ & $4.10(0.57)$ \\
\hline Murcia & $1.46(0.02)$ & $1.93(1.07)$ & $3.52(0.52)$ \\
\hline Navarre & $1.02(0.34)$ & $1.53(0.44)$ & $2.95(0.73)$ \\
\hline Basque Country & $1.63(0.85)$ & $1.76(0.62)$ & $2.52(0.90)$ \\
\hline Valencia & $1.00(0.32)$ & $0.62(0.32)$ & $2.73(0.08)$ \\
\hline
\end{tabular}

